\title{
Indikasi Moral hazard Dalam Penyaluran Pembiayaan Pada Perbankan Syariah di Indonesia
}

\author{
Teti Rahmawati \\ Universitas Kuningan \\ muhammadwafda@gmail.com
}

\begin{abstract}
Abstrak
Prinsip kehati-hatian dalam mengelola dana nasabah merupakan faktor penting untuk menjaga kepercayaan dari para nasabah. Berbagai kejadian moral hazard harus menjadi perhatian serius bagi para stakeholders bank syariah. Perlu disadari bahwa perbankan syariah, seperti institusi bisnis lainnya, tidak bebas dari praktik-praktik seperti: moral hazard, dan agency problem.

Penelitian ini bertujuan membuktikan apakah terdapat indikasi moral hazard dalam penyaluran pembiayaan pada perbankan syariah di Indonesia. Penelitian ini menggunakan metode explanatory survey. Untuk menguji hipotesis penulis menggunakan analisa data dengan metode analisis regresi berganda dan error correction modeling. Penilitian dilakukan terhadap 21 bank syariah. Pengumpulan data berasal dari data sekunder laporan publikasi Bank Indonesia dan Badan Pusat Statistik. Hasil penelitian menunjukkan bahwa terdapat indikasi moral hazard pada perbankan syarian di Indonesia.
\end{abstract}

Kata kunci : Bank syariah, moral hazard, pembiayaan, NPF

\section{PENDAHULUAN}

Prinsip kehati-hatian ketika melakukan pengelolaan dana nasabah merupakan faktor utama untuk menjaga kepercayaan para nasabah. Di Indonesia telah terjadi beberapa kasus moral hazard pada bank konvensional. Moral hazard yang melanda banyak pengurus bank di Indonesia membuat fundamental industri perbankan rapuh. Sebelum krisis meletus, pelanggaran batas maksimal pemberiaan kredit (BMPK) marak dilakukan oleh bank. Pertengahan 1997, kredit macet meledak dan terjadilah krisis perbankan. Pada saat itu kepercayaan masyarakat terhadap perbankan terus menurun dan meningkatnya penarikan dana masyarakat dari perbankan. Meningkatnya jumlah non performing loan semakin memperburuk kondisi perbankan di Indonesia. Bencana yang terjadi pada perbankan menjadi pelajaran penting industri perbankan Indonesia. Berdasarkan pelajaran itu, para bankir dituntut untuk memegang teguh prinsip kehati-hatian. Beberapa kasus moral hazard pada perbankan pun kembali berlangsung pasca krisis. Bahkan krisis keuangan global yang melanda dunia pada tahun 2008 juga dipicu oleh prilaku moral hazard dari para pelaku perbankan. Lehman Brothers mengalami kebangkrutan karena tidak bisa membendung masalah kredit macet.

Berbagai kejadian moral hazard tersebut, harus menjadi perhatian serius bagi para stakeholders bank syariah. Perbankan syariah adalah bagian dari institusi bisnis lainnya, maka harus 
diwaspadai adanya kemungkinan moral hazard, dan agency problem. Pada pembiayaan berbasis bagi hasil, misalnya Mudharabah, risiko moral hazard, dan agency problem sangat tinggi. Moral hazard terjadi ketika dalam suatu kontrak kerja sama, salah satu pihak melakukan tindakan yang menguntungkan dirinya sendiri yang dalam hal ini bertentangan dengan kontrak. Sementara agency problem terjadi ketika dalam perjanjian tersebut salah satu pihak berbuat sesuatu yang menyenangkan atau menguntungkan dirinya sendiri dan akibatnya harus dibayar oleh pihak lain. Dalam pembiayaan dengan akad mudharabah, antara bank syariah dengan pengusaha, bank sebagai rabbul mal, harus menanggung kerugian apabila bisnis yang dijalankan itu merugi. Dengan kondisi seperti ini, pengusaha yang tidak jujur dapat saja membuat laporan yang menggelembungkan biaya, sehingga pendapatan bersih menjadi mengecil atau bahkan merugi. Akibatnya tidak ada hasil yang dapat dibagi antara bank dengan pengusaha dan pengusaha dapat memakai dana tersebut untuk kepentingan dirinya, yang kemudian dibebankan kepada bank. Hal ini dapat terjadi, ketika pengusaha sebagai pelaksana memiliki informasi yang lebih memadai (assymmetric information) dibandingkan bank dalam bisnis yang sedang dijalankan, sehingga pengusaha dapat saja memanipulasi laporan keuangan proyek, sementara itu bank syariah hanya dapat menerima karena tidak memiliki kompetensi dalam bisnis yang sedang dibiayai.

Selain kemungkinan terjadi moral hazard pada sisi debitur, praktek moral hazard juga sudah terjadi pada lembaga perbankan syariah. Salah satu kasus mengenai moral hazard yang dilakukan oleh pimpinan bank syariah adalah kasus yang terjadi pada tahun 2007 di Bank Rakyat Indonesia Unit Usaha Syariah cabang Serang Banten, yang memberikan pembiayaan dengan tidak memperhatikan prinsip kehatihatian. Akibat kasus ini Bank BRI Syariah mengalami kerugian sebesar Rp169 milyar akibat pembiayaan macet. Berdasarkan data publikasi BI, sejak Januari hingga November 2007, non performing financing (NPF) perbankan syariah mengalami kenaikan hingga mencapai di atas level lima persen. Peningkatan pembiayaan bermasalah perbankan syariah sehingga lebih tinggi dibanding NPF perbankan konvensional pada tahun 2007 tersebut merupakan pekerjaan rumah yang harus diwaspadai industri perbankan syariah terutama kemungkinan adanya indikasi terjadi moral hazard pada perbankan syariah. Data menunjukkan bahwa dari mulai perbankan syariah berdiri hingga sampai awal tahun 2007, pembiayaan bermasalah pada perbankan syariah selalu lebih rendah apabila dibandingkan dengan NPL perbankan konvensional. Indikasi adanya moral hazard pada bank syariah di Indonesia telah ditemukan oleh peneliti diantaranya Mustafa Edwin Nasution \& Ranti Wiliasih, (2007) meyatakan bahwa dengan metode error correction model dalam keseimbangan jangka panjang terdapat indikasi moral hazard pada bank muamalat syariah.

Penelitian ini bermaksud untuk mendapatkan gambaran empiris mengenai adanya indikasi moral hazard dalam penyaluran pembiayaan di perbankan syariah.

Untuk mencapai maksud tersebut, tujuan yang ingin dicapai pada penelitian ini yaitu untuk mengetahui apakah terdapat indikasi 
moral hazard pada saat menyalurkan pembiayaan pada perbankan syariah di Indonesia

\section{Kajian Pustaka}

\subsection{Moral Hazard}

Irfan (2002) memberikan definisi asimetri informasi ialah suatu kondisi dimana ada kesenjangan perolehan informasi antara manajemen sebagai pemberi informasi dengan pemegang saham dan stake holder sebagai pengguna informasi. Ia menyatakan bahwa terdapat dua tipe asimetri informasi yaitu:

A. Adverse selection adalah para manajer sebagai agen serta orang-orang dalam lainnya bisanya mengetahui lebih banyak informasi mengenai keadaan dan prospek perusahaan apabila dibandingkan dengan investor sebagai pihak eksternal . Keberadaan informasi yang mungkin bisa mempengaruhi keputusan yang diambil oleh investor tersebut tidak disampaikan kepada investor sebagai principal

B. Moral hazard adalah aktivitas yang dilakukan manajer tidak diketahui seluruhnya oleh pemegang saham maupun pemberi pinjaman, yang menyebabkan manajer dapat melakukan tindakan diluar sepengetahuan investor yang melanggar kontrak dan sebenarnya secara norma atau etika mungkin tidak layak dilakukan.

Terbatasnya informasi tentang produktifitas usaha juga menjadi permasalahan yang dihadapi dalam rangka optimalisasi kinerja bank syariah. Dalam kegiatan usaha, mudharib mempunyai informasi yang lebih lengkap daripada shahibul mal. Shahibul mal, meskipun mempunyai data, namun bisanya tidak seakurat dan serinci mudharib sebagai pelaku usaha (Sofyan Rizal,).

Hal tersebut bisa menyebabkan mudharib memiliki keuntungan lebih karena memiliki informasi yang tidak dimikili oleh shahibul mal, dan bisa digunakan sebagai posisi tawar ketika melakukan bargaining pada saat menjalankan kotrak sharing. Pada perbankan syariah, pengungkapan informasi mengenai kinerja yang komprehensif sangat penting. Termasuk didalamnya informasi yang bisa memungkinkan nasabah untuk menilai sendiri seberapa besar keuntungan dan risiko yang diperoleh nasabah apabila menabung di bank syariah juga penting, karena pembagian keuntungan pada nasabah bank syariah bukan atas dasar bunga akan tetapi atas pembagian hasil investasi (Revenue Sharing) (Rizal Yahya,2008).

Asimetri informasi timbul ketika manajer lebih mengetahui informasi internal dan informasi tentang prospek perusahaan di masa yang akan datang jika dibandingkan dengan pemegang saham dan stakeholder lainnya. Sehingga beberapa konsekuensi hanya diketahui saatu pihak saja tanpa diketahui pihak yang lainya padahal juga memerlukan informasi tersebut (Silvia \& Yanivi : 2003). Posisi investor dalam mengakses informasi perusahaan lebih lemah dibandingkan dengan manajemen, sehingga menyebabkan tingginya asimetri informasi. Menurut Scott (2003:8) ada dua tipe asimetri informasi, yaitu adverse selection dan moral hazard.

Moral hazard timbul karena adanya pemisahan antara pengelola perusahaan dengan agen. Pemilik tidak bisa mengamati secara langsung kebijakan - kebijakan yang dilakukan manajemen. Jensen dan Meckling (1976) 
menyatakan bahwa kontrak yang dilakukan antara pemegang saham dengan manajer adalah suatu hubungan keagenan (agency relationship. Pemegang saham memberikan wewenang kepada manajer yang bertindak sebagai agen untuk mengelola perusahaan atas nama pemegang saham.

Bebczuk (2003) memberi penjelasan bahwa dalam setiap penyaluran kredit atau pembiayaan sebenarnya terdapat ketidakpastian (uncertainty) yakni, pertama, terhadap kemampuan membayar debitur. Ketidakpastian ini diantisipasi melalui melakukan estimasi kemungkinan kembalinya pinjaman secara penuh (probability of full reimbursement) dan penyesuaian pengenaan suku bunga. Kedua, kemungkinan debitur untuk melanggar perjanjian kredit yang sulit untuk diketahui oleh lender.

Dalam hal ini, debitur dapat berupaya untuk mengelabui lender mengenai kondisi usahanya sebenarnya, atau ketika pinjaman sudah diberikan maka debitur kemungkinan dapat saja menggunakan dana tersebut untuk kepentingan yang lain atau menyembunyikan hasil usaha yang sebenarnya dari proyek atau bidang usahanya yang dibiayai. Permasalahanpermasalahan tersebut dikenal sebagai asymmetric information problem. Lebih lanjut Bebczuk menjelaskan asymmetric information problem terdiri dari beberapa bentuk yakni: (i) adverse selection, (ii) moral hazard, dan (iii) monitoring cost.

Adverse selection adalah permasalahan pada lender ketika lender atau dapat juga disebut bank, tidak mampu membedakan proyek-proyek dengan masing-masing risiko yang melekat. Moral hazard adalah permasalahan yang terjadi ketika debitur menggunakan dana dari bank untuk kepentingan penggunaan lain di luar yang telah diperjanjikan dengan bank. Monitoring cost, adalah permasalahan dimana debitur mengambil keuntungan atas ketidakmampuan bank dalam menilai pendapatan sebenarnya dari usaha yang dibiayai bank, dengan mengatakan pendapatan yang diterima lebih rendah daripada kondisi sebenarnya.

Dreher (2004) menyebutkan bahwa program penjaminan atau bailout IMF di sejumlah negara telah mengakibatkan terjadinya moral hazard di negara-negara tersebut. Masih menurut Dreher berdasarakan pada moral hazard yang diajukan vaubel (1983) yang menyatakan pada dasarnya prinsip moral hazard berkembang ketika provisi dari asuransi memberikan kesempatan kepada pemegang polis asuransi untuk bertindak ceroboh sehingga memungkinkan terjadinya kondisi-kondisi yang buruk yang tidak diharapkan. Kondisi ini dianalogikan dengan sikap IMF yang memberikan bantuan pada negara yang mengalami guncangan ekonomi, yang menimbulkan kehati-hatian yang rendah dari negara tersebut untuk melawan krisis. Jika sikap ketidakhati-hatian yang dilakukan penerima asuransi dikategorikan sebagai moral hazard langsung, maka IMF sebagai pihak yang memberikan kesempatan terjadinya moral hazard disebut telah melakukan moral hazard tidak langsung.

Dari pernyaataan veubel tersebut maka ketidakhati-hatian bank dalam menyalurkan krediat atau pembiayaan dapat dikategorikan sebagai tindakan moral hazard. Moral hazard dalam dunia perbankan setidaknya dapat dibedakan atas 2 tingkatan. Pertama, 
moral hazard pada tingkat bank dan yang kedua adalah moral hazard di tingkat nasabah. Moral hazard di tingkat bank dapat dibedakan sebagai berikut :

a. Moral Hazard dalam kebijakan penyaluran pembiayaan, yaitu risky lending behavior yang menyebabkan timbulnya moral hazard dan adverse selection di tingkat nasabah karena lemahnya monitoring yang dilakukan bank syarah, yang disebut juga moral hazard tidak langsung (mengacu kepada pengertian moral hazard yang dikemukakan oleh Vaubel (1983) dalam Dreher (2004)).

b. Moral hazard karena ketidakhatihatian bank dalam menyalurkan pembiayaan karena adanya penjaminan dari pemerintah atau keberadaan lembaga penjamin simpanan dalam hal ini termasuk dalam moral hazard langsung (mengacu kepada pengertian moral hazard yang dikemukakan oleh Vaubel (1983) dalam Dreher (2004)).

c. Moral hazard pada saat penyaluran pembiayaan bank tidak mencerminkan bank sebagai lembaga intermediasi atau tidak meyalurkan dana kepada sektor riil.

d. Moral hazard ketika bank memberikan cost of fund yang rendah dan menerapkan tingkat yang tinggi, juga termasuk dalam kategori moral hazard dan lainnya.

\subsection{Pembiayaan Bank Syariah}

Kontrak hubungan investasi antara bank syariah dengan nasabah ini disebut pembiayaan (Muhammad, 2003). Pembiayaan bank syariah akan dijalankan dengan berbagai teknik dan metode yang penerapannya tergantung pada tujuan dan aktivitas seperti kontrak mudharabah, musyarakah, murabahah.
Dalam pelaksanaan pembiayaan, bank syariah harus memenuhi :

a. Aspek syariah, berarti dalam setiap realisasi pembiayaan kepada para nasabah bank syariah harus tetap berpedoman pada syariat islam (antara lain tidak mengandung unsur riba dan bidang usaha yang dibiayai harus halal

b. Aspek ekonomi, berarti disamping mempertimbangkan hal-hal syariah bank syariah juga harus harus tetap mempertimbangkan perolehan keuntungan baik bagi bank syariah maupun bagi nasabah bank syariah.

\subsubsection{Prinsip Kehati-hatian dalam menyalurkan Pembiayaan \\ Untuk ketentuan kehati-hatian,} BI telah mengeluarkan dua peraturan Bank Indonesia (PBI) yang khusus mengatur perbankan syariah, yaitu PBI tentang Kualitas Aktiva Produktif bagi bank syariah dan PBI tentang Penyisihan Penghapusan Aktiva produktif bagi bank syariah. Penerbitan PBI tersebut dilatarbelakangi oleh adanya beberapa produk penanaman dana dalam bentuk aktiva produktif yang relatif berbeda dengan produk perbankan konvensional. Setiap kebijakan pembiayaan bank yang dibuat wajib memuat dan menetapkan dengan jelas dan tegas prinsip kehatihatian, dan minimal harus meliputi kebijakan pokok perkreditan, tata cara penilaian mutu, profesionalisme dan integritas pejabat perkreditan.

\subsubsection{Konsep Pembiayaan Bermasalah /Non Performing Financing}

Menurut Mahmoedin (2004) setiap kredit macet adalah kredit bermasalah, tetapi setiap kredit bermasalah belum tentu kredit macet. Karena mungkin saja kredit tersebut bermasalah, tetapi sama sekali belum macet. Kredit bermasalah 
(Non Performing Loan/ Problem Loan) atau Non Performing Financing (NPF) bagi bank syariah ialah pembiayaan yang masuk pada kategori pembiayaan kurang lancar, diragukan, dan macet berdasarkan kriteria yang sudah ditetapkan oleh Bank Indonesia. Status NPF didasarkan atas ketepatan waktu bagi nasabah untuk membayarkan kewajiban sesuai akad perjanjian yang telah disepakati. Proses pemberian dan pengelolaan pembiayaan yang baik diharapkan dapat menekan NPF sekecil mungkin.

Beberapa pengertian mengenai kolektivitas kredit yang dibuat menurut ketentuan Bank Indonesia (Martono, 2002: 61) adalah sebagai berikut:

1) Kredit lancar, yaitu kredit yang pembayaran pokok pinjaman dan bunganya tepat waktu, perkembangan rekening baik dan tidak ada tunggakan serta sesuai dengan persyaratan kredit.

2) Kredit dalam perhatian khusus, yaitu kredit yang pengembalian pokok pinjaman atau bunganya terdapat tunggakan sampai 90 hari.

3) Kredit kurang lancar, yaitu kredit yang pengembalian pokok pinjaman dan pembayaran bunganya terdapat tunggakan telah melampaui 90 hari sampai 180 hari waktu yang disepakati.

4) Kredit diragukan, yaitu kredit yang pengembalian pokok pinjaman dan pembayaran bunganya terdapat tunggakan telah melampaui 180 hari sampai dengan 270 hari dari waktu yang disepakati.

5) Kredit macet, yaitu kredit yang pengembalian pokok pinjaman dan pembayaran bunganya terdapat tunggakan telah melampaui 270 hari.

Tingginya NPF sangat

dipengaruhi oleh kemampuan bank dalam menjalankan proses pemberian pembiayaan dengan baik maupun dalam hal pengelolaan pembiayaan, termasuk tindakan pemantauan (monitoring) setelah pembiayaan disalurkan dan tindakan pengendalian bila terdapat indikasi penyimpangan pembiayaan maupun indikasi gagal bayar.

\subsubsection{Faktor-Faktor Penyebab Non} Performing Financing (NPF)

Faktor-faktor yang menyebabkan

NPF dapat dikategorikan kedalam tigakelompok yaitu: faktor internal bank, faktor kondisi debitur (termasuk calon debitur), dan faktor eksternal.

A. Faktor internal bank

Faktor internal bank adalah halhal berkaitan dengan kondisi Sumber Daya Manusia (SDM) bank itu sendiri, kualitas proses bisnis bank, dan keterlibatan pihak lain dalam bisnis. Kondisi SDM menyangkut seberapa jauh integritas, kelalaian, kesengajaan, dan kemungkinan melakukan moral hazard dari komisaris, direksi, dan karyawan untuk memenuhi kebutuhan bank dalam menjalankan bisnisnya. Kualitas proses bisnis bank berkaitan dengan strategi pemasaran yang diterapkan, pengambilan kebijakan pembiayaan, kualitas proses persetujuan Pembiayaan, syarat pemberian Pembiayaan, kualitas proses penagihan, proses pengawasan dan pengendalian. Sedangkan keterlibatan pihak lain dalam bisnis bank terutama terkait dengan penerapan linkage program dalam pengembangan usaha bank melalui kerjasama dengan pihak lain seperti bank umum.

B. Faktor kondisi debitur

Faktor kondisi debitur pada umumnya dikategorikan berdasarkan $5 \mathrm{C}$ (character, capacity, capital, collateral, dan condition). Dalam prakteknya kelima komponen $\mathrm{C}$ tersebut diurutkan ke dalam credit rating atau credit 
scoring sehingga bank bisa menilai risiko yang ditanggungnya ketika menyalurkan Pembiayaan kepada nasabah-nasabahnya.

C. Faktor eksternal

Faktor eksternal terdiri dari komponen variabel Makro ekonomi (GDP, Inflasi)

\section{1) Gross Domestic Product (GDP)}

Mankiw (2001) menyatakan bahwa Produk Domestik Bruto (PDP) atau Gross Domestic Product (GDP) ialah nilai pasar semua barang dan jasa akhir yang diproduksi oleh Negara dalam kurun waktu tertentu. GDP menghitung dua sekaligus yaitu pendapatan total setiap orang dalam suatu perekonomian dan pengeluaran total atas seluruh output. Untuk perekonomian secara keseluruhan, pendapatan sama dengan pengeluaran. GDP nominal seringkali disebut GDP atas dasar harga berlaku) merujuk pada nilai GDP tanpa memperhatikan pengaruh harga. Sedangkan GDP riil (atau disebut GDP atas dasar harga konstan) mengoreksi angka GDP nominal dengan memasukkan pengaruh dari harga.

\section{2) Inflasi}

Inflasi adalah kecenderungan dari harga untuk meningkat secara umum dan terus menerus. Kenaikan harga atas satu atau dua barang saja tidak bisa disebut inflasi kecuali apabila kenaikan tersebut meluas (atau menyebabkan kenaikan) kepada barang-barang yang lainnya. Aliminsyah dan Padji (2004) memberikan definisi inflasi sebagai berikut "suatu keadaan yang menunjukkan jumlah peredaran uang yang lebih banyak dari pada jumlah barang yang beredar, sehingga menimbulkan penurunan daya beli uang dan selanjutnya terjadi kenaikan harga yang mencolok.

Downes dan Elliot Goodman(2003) mengatakan, inflasi adalah kenaikan dalam harga barang dan jasa, yang terjadi jika pembelanjaan bertambah dibandingkan dengan penawaran barang di pasar (dengan kata lain terlalu banyak uang yang memburu barang yang terlalu sedikit).

Bank Indonesia mendefinisikan inflasi dengan kecenderungan dari hargaharga untuk meningkat secara umum dan terus menerus.Badan kebijakan fiskal Departemen Keuangan mendefinisikan inflasi dengan sebuah proses kenaikan harga-harga secara umum dan berkelanjutan sebagai akibat adanya ketidakseimbangan (excess demand) dalam perekonomian.

\subsubsection{Kerangka pemikiran Indikasi Moral Hazard dalam penyaluran pembiayaan pada bank syariah}

Moral hazard pada bank terjadi pada saat bank syariah sebagai mudharib kurang berhati-hati dalam menyalurkan pembiayaan sehingga menimbulkan potensi adanya moral hazard di sisi nasabah yang bisa menyebabkan kerugian. Moral hazard lainnya terjadi ketika bank tidak membayarkan haknya shahibul maal sberdasarkan rasio yang ditetapkan pada saat awal pelaksanaan perjanjian, atau ketidakpatuhan bank syariah pada prinsip syariah, juga bisa dikategorikan sebagai tindakan moral hazard. Moral hazard pada sisi nasabah biasanya terjadi pada produk pembiayaan yang berbasis pembiayaan modal (mudharabah dan musyarakah) atau biasa dikenal dengan profit loss sharing. Akad mudharabah tidak mensyaratkan 
adanya jaminan serta memberikan hak penuh kepada mudharib untuk menlaksanakan usaha tanpa campur tangan dari shahibul maal dan ditanggungnya kerugian oleh shahibul maal (kecuali akibat kesalahan yang dilakukan oleh manajemen) menyebabkan akad pembiayaan ini rentan terhadap masalah moral hazard. Moral hazard pada sisi nasabah merupakan isu yang menyebabkan bank syariah lebih memilih pembiayaan dengan basis jual beli (murabahah, ishtisna, dan salam).

Pada penelitian ini, moral hazard dibatasi pada peran bank syariah sebagai mudharib yang bertanggung jawab atas dana yang diamanahkan oleh shahibul maal (mengacu kepada definisi dari Vaubel (1993) yang dikutip oleh Dreher (2004)). Ketika bank syariah memperoleh amanah dari deposan baik berupa tabungan wadiah maupun tabungan mudharabah, maka bank syariah diharuskan menyalurkan dana tersebut pada pembiayaan yang layak untuk dibiayai dan sesuai dengan prinsip syariah. Bank syariah harus menerapkan prinsip kehati-hatian ketika menyalurkan pembiayaan untuk menghindari kemungkinan gagal bayar (default) dari para debitur (penerima pembiayaan). Prinsaip kehati-hatian dilakukan untuk mengurangi moral hazard dari sisi nasabah. Ketika bank syariah menerapkan prinsip kehatianhatian dengan baik diharapkan bank syariah memiliki keyakinan bahwa nasabah yang menerima pembiayaan mempunyai niat baik untuk membayar kewajibannya yaitu melunasi pembiayaan.

Itikad baik dari nasabah menjadi penting bagi bank syariah karena kegagalan bayar pada nasabah yang diakibatkan oleh moral hazard pada sisi nasabah dalam situasi tertentu menggambarkan telah terjadinya indikasi moral hazard tidak langsung dari sisi bank syariah sebagai akibat tidak menerapkannya prinsip kehatihatian.

Keadaan ini digambarkan oleh Ghosal\&Miller (2003) dalam penelitiannya yang menjelaskan bahwa ada dua karakter nasabah yang menyebabkan gagal bayar atas kredit yang diberikan perbankan. Yang pertama adalah nasabah dengan good effort dan kedua nasabah bad effort. Ketika kondisi perkenomian ada pada keadaan baik (tidak ada shock) maka nasabah yang memiliki good effort akan membayarn kreditnya dengan baik (no default) akan tetapi ketika terjadi kegoncangan ekonomi bisa memungkinkan terjadinya gagal bayar (default). Sedangkan nasabah dengan bad effort bisa memungkinkan untuk gagal bayar (default) ketika kondisi perekonomian dalam kondisi bagus maupun ketika perekonomian sedang mengalami goncangan.

Prinsip kehati-hatian harus selalu dipegang oleh perbankan syariah pada saat akan menyalurkan pembiayaan terkait dengan risiko gagal bayar yang terjadi seperti yang telah jelaskan sebelumya.

Beberapa bank yang mengalami kesulitan likuiditas dan mengalami kebangkrutan berawal dari kredit macet yang disebabkan oleh adanya karakter nasabah yang kurang baik, serta disebabkan oleh fasilitas kredit yang diberikan pada perusahaan yang masih berada dalam satu grup kepemilikan. Hal tersebut mengindikasikan adanya moral hazard pada sisi perbankan.

Ding Lu,dkk 2001 menjelaskan hubungan antara kebijakan kredit bank memiliki hubungan yang erat dengan 
besaran kredit bermasalah. Pemberian kredit yang lebih tinggi kepada perusahaan daerah serta menjelaskan kebijakan bank untuk menyalurkan tambahan kredit pada perusahaan yang mengalami kesulitan keuangan berkontribusi pada terbentuknya non performing loan dan membuka kesempatan terjadinya moral hazard dari sisi debitur.

Beberapa penelitian juga memperlihatkan bahwa ada trade off antara risk sharing dan moral hazard. Dalam penelitian Gaynnor Martin, dan Gertler(1995) menjelaskan pilihan bagi perusahaan bahwa untuk menggunakan risk sharing atau mengorbankan insentif efisiensi akan tergantung pada penerimaan risiko. Hal ini menjadi penting untuk menyelidiki trade of antara moral hazard dan risk sharing.

Penelitian lain yaitu diungkapkan oleh Suthep Kittikulsingh yang membahas non performing loan dari sisi nasabah. Ia menyatakan bahwa ketika tingkat bunga tinggi pengusaha mengalami kesulitan untuk membayar Pembiayaannya. Berikitnya Kittikulsings juga meneliti bahwa ketika pertumbuhan GDP $-10 \%$, setengah dari total pinjaman akan macet dan sebagian ekuitas dari sistem bank akan hilang. Lindiawati (2007), mengemukakan bahwa faktor eksternal dengan menggunakan indikator makro ekonomi GDP, suku bunga, dan inflasi mempunyai pengaruh terhadap pembiayaan macet pada perbankan syariah. Demikian juga faktor internal perubahan modal mempunyai akibat atau pengaruh yang erat dengan pembiayaan macet

Mustafa Edwin Nasution dan Ranti Wiliasih (2007) dengan menguunakan Error Correction Model, untuk kasus Bank Syariah Mandiri (BSM) tidak ditemukan adanya indikasi moral hazard. Hal ini disebabkan pembiayaan BSM lebih difokuskan kepada pembiayaan dengan skema murabahah sehingga lebih berhati-berhati ketika melakukan maintenance pada pembiayaan tersebut. Untuk kasus BMI, rasio alokasi pada pembiayaan murabahah terhadap pembiayaan dengan skema profit loss sharing (mudharabah dan musyarakah) menyebabkan meningkatnya kredit macet. Hal tersebut memberikan indikasi adanya moral hazard di BMI, yaitu ketidakhati-hatian BMI sehingga menyebabkan terjadinya moral hazard pada sisi debitur. Komposisi yang seimbang antara pembiayaan murabahah dan mudharabah, di duga menyebabkan BMI melakukan pengawasan yang lebih ketat untuk debitur pada pembiayaan musyarakah dan mudharabah, akan tetapi kurang waspada pada pembiayaan murabahah. Adanya indikasi moral hazard menujukkan adanya sistem di bank syariah yang harus ditata seperti penilaian kelayakan calon debitur, sistem pengawasan dan sistem operasional lainnya yang bisa mereduksi moral hazard di sisi nasabah.

Berdasarkan penjelasan yang dipaparkan diatas maka untuk menjawab apakah ada indikasi moral hazard pada bank syariah dapat dilihat dari faktorfaktor yang mempengaruhi non performing financing di bank umum syariah. Faktor penyebab NPF terdiri dari variabel makro ekonomi yang diproksikan oleh GDP, inflasi dan faktor kebijakan pembiayaan (Wu, Chang dan Selvili, 2003).

Indikasi adanya Moral hazard terjadi apabila pada saat GDP meningkat ternyata pada saat yang sama NPF juga meningkat. Idealnya, ketika GDP meningkat maka terjadi 
peningkatan transaksi ekonomi, dunia bisnis lebih menggeliat sehingga jika pada kondisi tersebut NPF meningkat, mengindikasikan bank kurang berhatihati atau kurang melakukan monitoring.

Indikasi moral hazard lainnya terjadi jika NPF meningkat pada saat tingkat inflasi menurun. Idealnya, ketika harga- harga cenderung turun, maka para mudharib lebih mampu untuk melunasi kewajibannya. Jika pada kondisi ini terjadi kenaikkan NPF maka mengindikasikan adanya moral hazard pada bank syariah karena bank kurang berhati-hati atau kurang monitoring. Jika kondisi makro ekonomi dalam kondisi baik yang ditandai dengan GDP yang meningkat dan turunnya inflasi, maka idealnya NPF akan turun ( ada hubungan negatif antara kondisi makroekonomi) sebagaimana hipotesis dari wu chang dan sevilli (2003).

Dalam kondisi perekonomian baik idealnya NPF akan turun) dan juga penelitian dari Kittikulsingh(2002), Bahwa GDP akan mempengaruhi kemampuan nasabah dalam membayar kreditnya. Jika hubungan yang terjadi searah yaitu GDP meningkat dan NPF meningkat berarti ada indikasi bahwa telah terjadi moral hazard pada tingkat nasabah. Dan pada saat bank tidak mampu mengcounter kondisi tersebut. Maka hal ini mengindikasikan adanya moral hazard pada bank syariah.

Indikasi moral hazard yang terakhir dapat dilihat dari kebijakan pembiayaan yang kurang berhati-hati dan menyebabkan terjadinya peningkatan NPF/NPF. Pembiayaan dengan akad bagi hasil memiliki risiko yang lebih tinggi dibanding dengan pembiayaan dengan akad jual beli. Dalam hal ini bank syariah harus siap dengan berbagi untung dan berbagi rugi.
Apabila kebijakan bank syariah memberikan bagian yang lebih besar pada pembiayaan dengan prinsip bagi hasil maka seharusnya antisipasi bank syariah terhadap keungkinan meningkatnya non perrforming financing akan lebih tinggi. Dengan demikian apabila terjadi penurunan pada proporsi pembiayaan dengan prinsip bagi hasil tetapi non performing financing menjadi lebih inggi mengindikasikan bahwa bank syariah kurang berhati-hati dan atau kurang monitoring sehingga bank kurang melakukan antisipasi terhadap terjadinya moral hazard di sisi debitur (Covietz dalam Monitoring,market power and moral hazard)

Dengan kata lain jika bank syariah mengeluarkan kebijakan yang cenderung berhati-hati, dimana memberikan alokasi yang lebih besar pada pembiayaan yang tidak beresiko dibandingkan dengan pembiayaan yang berisiko, maka idealnya kebijakan tersebut akan menurunkan NPF. Namun jika kebijakan bank banyak memberikan pembiayaan yang berisiko rendah, akan tetapi nilai NPF juga mengalami peningkatan, maka ini mengindikasikan adanya moral hazard pada di bank syariah. Berarti bank syariah belum sepenuhnya berhatihati dalam mengelola pembiayaan yang mereka berikan kepada nasabah. Apabila dalam penyaluran pembiayaan telah menerapkan prinsip kehati-hatian ada kemungkinan bank syariah kurang melakukan monitoring sehingga terjadi pembiayaan bermasalah. 


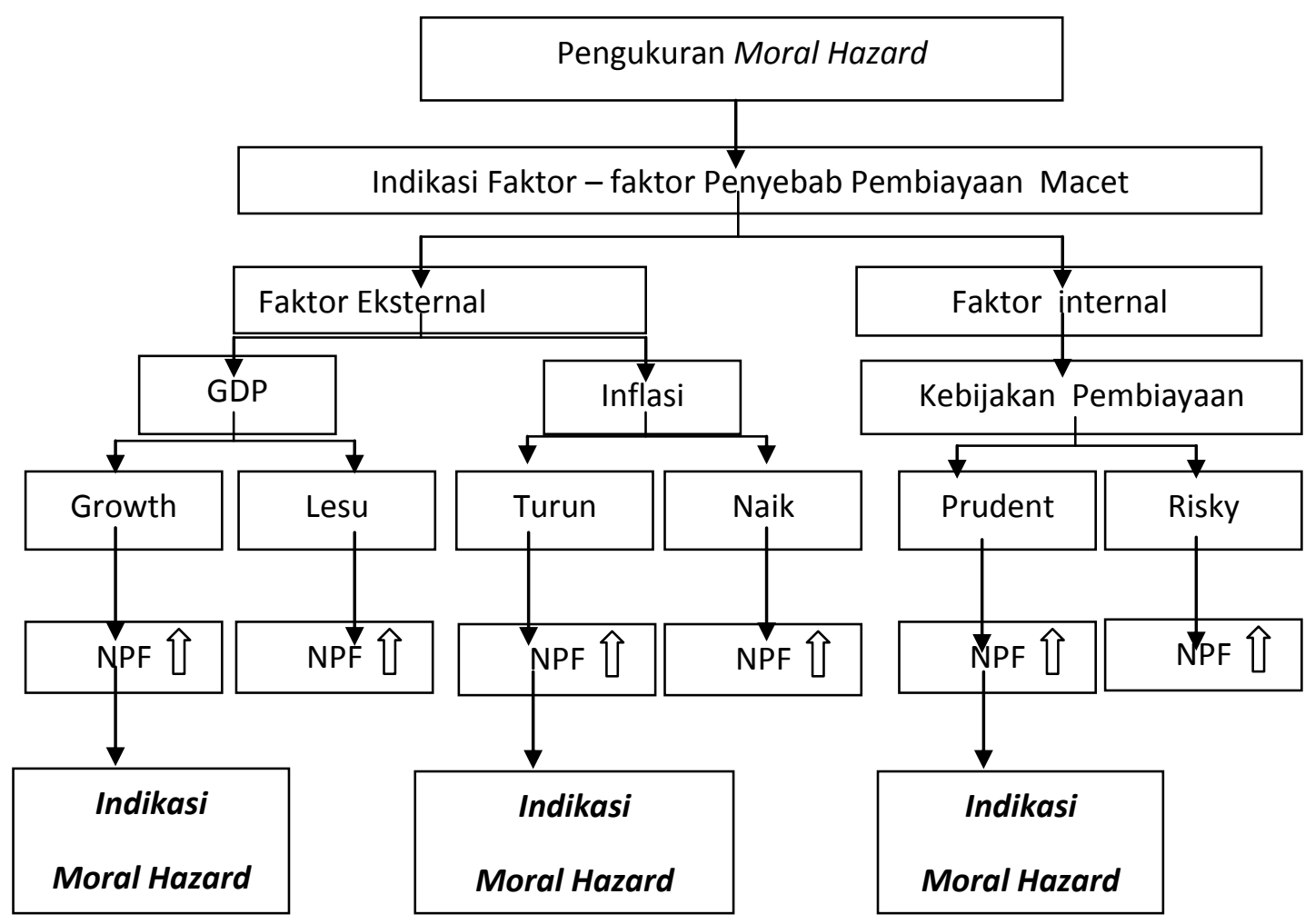

Gambar 2.2

Bagan Kerangka Pemikiran Indikasi Moral Hazard (Model 1)

Diadaptasi dari : Wu Chang \& Savili, Mustafa Edwin nasution(2007)

Dari penjelasan diatas maka penulis menetapkan hipotesa penelitian bahwa : " terdapat indikasi moral hazard dalam menyalurkan pembiayaan pada perbankan syariah di Indonesia “

\section{Metodologi Penelitian}

Metode penelitian ini dirancang sebagai penelitian explanatory survey yang bersumber pada data sekunder, berupa data-data keuangan dari bank umum syariah dan bank umum yang membuka unit usaha syariah.

Adapun model yang digunakan dalam penelitian ini mengadaptasi model penelitian dari Wu Chang dll yang mencoba menjelaskan non performing loan dengan empat variabel yaitu GDP, harga rumah dan rasio suku bunga pinjaman untuk kredit properti dibanding suku pinjaman lainnya. Variabel rasio suku bunga real estate dibandingkan dengan suku bunga pinjaman rata-rata/ kebijakan pembiayaan, dijadikan instrumen untuk mengukur keseriusan bank dalam mencegah terjadinya indikasi moral hazard dan adverse selection.

Dengan mengadopsi model diatas, melakukan sejumlah modifikasi dan penyesuaian dengan karakteristik bank syariah maka model penelitian yang penulis gunakan dalam penelitian ini diuraikan sebagai berikut. Model ini digunakan untuk menggambarkan seberapa jauh kebijakan pembiayaan bank syariah berkontribusi terhadap rasio pembiayaan macet. Banyaknya pembiayaan macet sekaligus menggambarkan ada tidaknya indikasi moral hazard dalam penyaluran 
pembiayaan di bank syariah. Model tersebut adalah sebagai berikut :

$N P F=\alpha_{0}+\alpha_{1} G D P+\alpha_{2} \operatorname{Inf}+\alpha_{3} \frac{P M}{P L S}+\varepsilon$ (3.1)

Dimana :

$\mathrm{NPF}=$ Non Performing Financing

GDP $=$ Gross Domestic Product

Inf $=$ Inflasi

PM/PLS = Rasio piutang Murabahah dengan pembiayaan profit loss sharing (mudharabah dan murabahah)

Berdasarkan hipótesis penelitian yang diajukan dalam penelitian ini, maka dirumuskan hipotesa statistik yang akan diuji sebagai berikut:

$\mathrm{H} 0_{1}=0$ Tidak terdapat indikasi moral hazard pada penyaluran pembiayaan di bank syariah

$\mathrm{Ha}_{1} \neq 0$ Terdapat indikasi moral hazard pada penyaluran pembiayaan di bank syariah

\section{Hasil Penelitian dan Pembahasan 4.1.Gambaran Indikasi Moral Hazard Pada perbankan Syariah}

Prinsip kehati-hatian dalam mengelola dana nasabah merupakan faktor penting dalam upaya menjaga kepercayaan para nasabah. Dalam beberapa tahun ini di Indonesia terjadi beberapa kasus moral hazard yang terjadi pada bank konvensional. Beberapa kasus yang terjadi misalnya, seorang kepala cabang Bank Umum Majapahit Jaya di Surabaya menggunakan blangko deposito untuk mendapatkan kredit Rp 39,7 miliar dan membuat lima bank swasta lain mengalami kerugian. Pada 1993, seorang kepala cabang Bank Rakyat Indonesia (BRI) Madiun merugikan banknya hingga Rp 6,8 miliar. Kasus pencairan dana untuk penyaluran kredit $\mathrm{Rp} 1,3$ triliun dari Bank Pembangunan
Indonesia (Bapindo) ke pengusaha Eddy Tansil. Bank Duta pada 1996. Kepala cabangnya di Balikpapan, Kalimantan Timur, merugikan nasabahnya sebesar Rp 1,5 miliar. Dua cabang Bank Maluku masing-masing Rp 1,4 miliar dan 200 juta pada 1998 mengalami hal yang sama.

Moral hazard yang melanda banyak pengurus bank di Indonesia membuat fundamental industri perbankan rapuh. Sebelum krisis meletus, pelanggaran batas maksimal pemberiaan/pembiayaan (BMPK) marak dilakukan oleh bank-bank papan atas. Pertengahan 1997, Pembiayaan macet pun meledak dan krisis perbankan tak terelakan lagi. Pada saat itu kepercayaan masyarakat terhadap perbankan terus menurun dan meningkatnya penarikan dana masyarakat dari perbankan.

Berbagai kejadian moral hazard tersebut, menjadi perhatian serius bagi para stakeholders bank syari'ah yaitu pemilik atau pemegang saham, komisaris, direksi, karyawan, Dewan Pengawas Syari'ah, nasabah dan para akademisi ekonomi syari'ah lainnya. Perlu disadari bahwa perbankan syariah, belum bias bebas murni dari praktikpraktik seperti: moral hazard, dan agency problem. Meskipun menurut Prof. Rodney Wilson dari University of Durham, Inggris, bahwa dalam perbankan syariah risiko moral hazard adalah kecil, namun ketika melihat kondisi Indonesia yang sangat korup, pernyataan di atas patut dipertanyakan validitasnya (Muhammad Fany Alfarisi,2004).

Selain kemungkinan terjadi moral hazard pada sisi debitur, praktek moral hazard juga sudah terjadi pada lembaga perbankan syariah. Salah satu kasus mengenai moral hazard yang dilakukan oleh pimpinan bank syariah adalah kasus 
yang terjadi pada tahun 2007 di Bank Rakyat Indonesia Unit Usaha Syariah cabang Serang Banten, yang memberikan pembiayaan dengan tidak memperhatikan prinsip kehatia-hatian. Akibat kasus ini Bank BRI Syariah mengalami kerugian sebesar Rp169 milyar akibat pembiayaan macet.

Kasusnya bermula dari kerjasama dua perusahaan properti dengan direktur cabang dan account officer BRI Syariah cabang Serang. Bank memberikan pembiayaan sebesar Rp 226 milyar untuk membiayai 3 proyek perumahan mewah. Pembiayaan dilakukan dengan skema murabahah yaitu pembiayaan dengan prinsip jual beli secara syariah. Dengan aturan jika properti sudah selesai dibangun maka kedua perusahaan tersebut yaitu PT NJS dan PT JAB harus menjual rumah tersebut kepada bank. Selanjutnya PT NJS dan PT JAB harus mencarikan pembeli rumah.

Setelah kredit cair PT NJS dan

PT JAB mendatangkan ratusan nasabah fiktif ke kantor BRI unit usaha syariah cabang serang untuk menandatangani akad pembiayaan sebagai pembeli fiktif properti tersebut. Ratusan nasabah yang dibuat fiktif tersebut merupakan warga miskin yang tinggal disekitar Jakarta yang mendapat penghasilan rendah rendah dan sama sekali tidak layak mendapatkan fasilitas pembiayaan untuk pemilikan properti senilai Rp800 juta . Mereka dimanfaatkan dengan cara mendapatkan paket berwisata ke pantai Anyer dengan mendapatkan fasilitas penginapan, uang saku dan akomodasi lainnya selama beberapa hari. Dalam perjalanan mereka mampir ke kantor BRI unit usaha syariah cabang Serang untuk menandatangani sejumlah dokumen untuk persyaratan pembiayaan. (Gatra, Edisi 7-13Mei2009)
Simbol agama tidak bisa menjamin sebuah lembaga bersih dari perilaku yang menyimpang. Pengelolanya adalah manusia biasa yang seringkali tergoda oleh harta dunia. Sebelum terjadinya kasus yang bisa mencoreng lembaga syariah, maka sejak dini perlu menjadi perhatian bagi semua pihak-pihak terkait agar berkomitmen menjauhi setiap penyimpangan yang mungkin terjadi.

Bank Indonesia mengeluarkan data pyublikasi dimana mengungkapkan bahwa sejak Januari hingga November 2007, non performing financing (NPF) perbankan syariah mengalami kenaikan hingga mencapai di atas level lima persen. NPF tertinggi terjadi pada Agustus 2007 pada kisaran 6,63 persen dengan nilai pembiayaan bermasalah mencapai $\mathrm{Rp} 1,633$ triliun dari total pembiayaan Rp 24,638 triliun. Dari pembiayaan bermasalah pada Agustus itu, nilai pembiayaan macet mencapai 2,99 persen atau Rp 736,982 miliar.

Rasio pembiayaan bermasalah perbankan syariah per September 2007 mencapai 6,29 persen, meningkat dibanding periode sama 2006 sebesar 5,13 persen. Meskipun pembiyaan bermasalah kembali menunjukan penurunan pada awal tahun 2008 hingga data terakhir menunjukkan bahwa pada bulan maret mencavai level 4,07 \%. Berikut digambarkan pergerakan jumlah pembiyaan bermasalah : 
Tabel 4.1

Perkembangan Non Performing Financing Perbankan Syariah

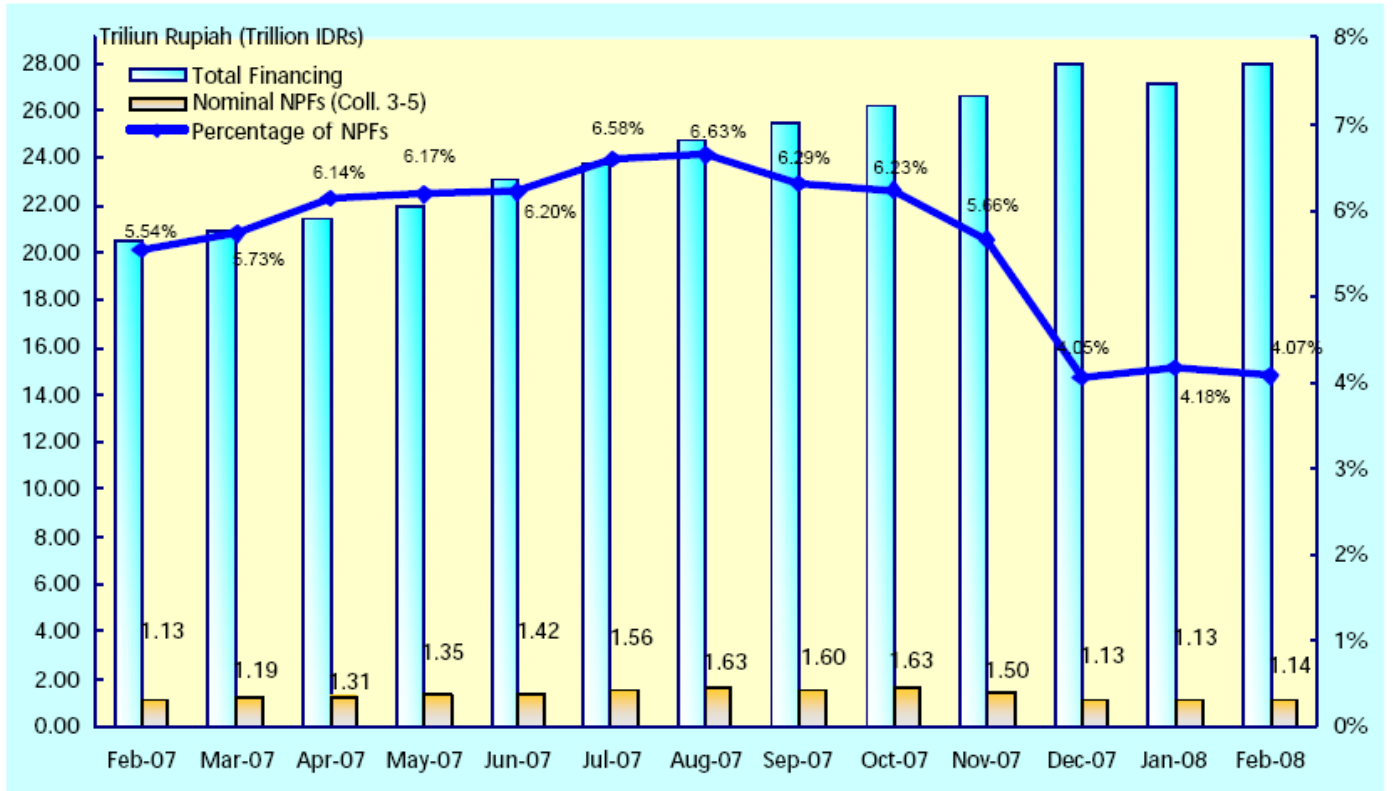

Sumber : Laporan statistik bank Indonesia Februari tahun 2008

Peningkatan NPF perbankan syariah yang lebih tinggi jika dibanding kan dengan NPF perbankan konvensional pada tahun 2007 tersebut merupakan pekerjaan rumah yang harus diwaspadai industri perbankan syariah terutama kemungkinan adanya indikasi terjadi moral hazard pada perbankan syariah. Data menunjukkan bahwa selama kurun waktu perbankan syariah berdiri pertama kali sampai dengan awal tahun 2007, NPF bank syariah selalu lebih rendah jika dibandingkan dengan NPL perbankan konvensional.

\subsection{Hasil Penelitian}

Sebagaimana dikemukakan diawal bahwa data yang digunakan untuk pengujian ada tidaknya indikasi moral hazard di perbankan syariah menggunakan data time series. Data dengan time series sering tidak stationer yang menyebabkan hasil regresi lancung dimana hasil regresi menunjukkan koefisien regresi yang signifikan secara statistik dan nilai koefisien determinasi tinggi namun hubungan antar variabel didalam model tidak saling berhubungan.

Data yang tidak stationer seringkali menunjukkan hubungan ketidakseimbangan dalam jangka pendek, tetapi ada kecenderungan terjadinya hubungan keseimbangan dalam jangka panjang. Untuk itu metode yang tepat untuk menguji data yang tidak stationer adalah dengan menggunakan Error Corection Modelling.

Berdasarkan hasil diatas maka model yang tepat bagi data time series yang tidak stationer adalah model koreksi kesalahan (Error Correction Modelling). Data yang tidak stationer bisa menunjukkan bahwa ada hubungan ketidakseimbangan dalam jangka pendek, tetapi memiliki kecenderungan adanya hubungan keseimbangan dalam 
jangka panjang. Langkah langkah untuk melakukan uji error correction modelling adalah sebagai berikut :

\section{A. Uji Stasioneritas}

Satu hal yang seringkali ditemui pada data time series adalah masalah stasioneritas data. Pada umumnya data ekonomi yang runtut waktu dan memiliki volatilitas yang tinggi tidak stationer pada data level. Kondisi data yang tidak stationer ini dapat diketahui dengan menggunakan model grafik correlogram, maupun uji akar unit. Stationeritas data menjadi penting karena jika data yang tidak stationer dilakukan regresi maka hasil yang diperoleh akan bersifat spurious nonsense regression yaitu signifikan secara statistik namun tidak memiliki arti secara eknomi dari masing-masing variabel. Untuk itu langkah utama yang dilakukan dalam pengolahan data adalah melakukan uji stationeritas. Uji stationeritas yang digunakan dalam penelitian ini adalah uji akar unit atau unit root test.

Untuk mendukung hasil pengamatan visual terhadap stationeritas data, maka selanjutnya dilakukan uji akar dengan Dickey Fuller Test dan Augmented Dickey Fuller test. Stationer atau tidaknya data dapat diketahui dari nilai ADF lebih besar dari nilai $M c$ Kinnon Critical Value pada tingkat signifikansi tertentu (1\%, 5\% maupun 10 $\%)$ berarti kondisi data stationer.

Dari hasil perhitungan diperoleh nilai absolut statistik $\mathrm{t}$ lebih kecil daripada nilai kritis pada tabel MacKinnon pada berbagai tingkat kepercayaan dan probabilitas yang lebih besar dari 0,05 menunjukkan bahwa data GDP tidak stasioner. Nilai absolut statistik t lebih besar daripada nilai kritis pada tabel MacKinnon pada berbagai tingkat kepercayaan dan probabilitas yang lebih kecil dari 0,05 menunjukkan bahwa data inflasi stasioner. Nilai absolut statistik $\mathrm{t}$ lebih kecil daripada nilai kritis pada tabel MacKinnon pada berbagai tingkat kepercayaan dan probabilitas yang lebih besar dari 0,05 menunjukkan bahwa data kebijakan pembiayaan tidak stasioner. Nilai absolut statistik t lebih besar daripada nilai kritis pada tabel MacKinnon pada berbagai tingkat kepercayaan dan probabilitas yang lebih kecil dari 0,05 menunjukkan bahwa data NPF stasioner.

\section{B. Uji Integrasi}

Berdasarkan pengujian deteksi akar unit dickey fuller diketahui bahwa data GDP dan kebijakan pembiayaan mengandung akar unit dengan kata lain datanya tidak stationer pada data level. Untuk menghindari masalah regresi lancung ini maka harus mentransformasi data yang tidak stationer menjadi stationer dengan menggunakan metode augmented dickey fuller selanjutnya disingkat ADF.

Seperti pada uji akar-akar unit sebelumnya, keputuisan sampai pada derajat keberapa suatu data akan stationer dapat dilihat dengan membandingkan antara nilai statistik ADF yang diperoleh dibandingkan dengan nilai kritisnya. Jika nilai absolut dari statistik ADF lebih besar dari nilai kritisnya pada diferensi tingkat pertama maka dapat dikatakan stationer pada tingkat satu. Dari tabel hasil uji integrasi pada variabel GDP memperoleh hasil bahwa nilai probabilitas lebih kecil dari 0,05 serta nilai absolut statistik t lebih besar dari nilai kritis pada tabel MacKinnon pada berbagai tingkat kepercayaan, oleh karena itu berarti data GDP stasioner diferensi pertama. Demikian juga untuk variabel kebijakan pembiayaan daari tabel hasil uji integrasi terhadap variabel tersebut diperoleh 
bahwa nilai probabilitas lebih kecil dari 0,05 dan nilai absolut statistik $t$ lebih besar daripada nilai kritis pada tabel MacKinnon pada berbagai tingkat kepercayaan, oleh karena itu berarti data kebijakan pembiayaan stasioner pada diferensi pertama.

\section{Uji Kointegrasi}

Alternatif uji kointegrasi yang sekarang banyak digunakan adalah uji 8ikointegrasi yang dikembangkan oleh Johansen. Hubungan jangka panjang (kointegrasi) dijelaskan dalam matrik dari sejumlah $\rho$ variabel. Ada atau tidaknya kointegrasi didasarkan pada uji likelihood ratio (LR) . Apabila nilai hitung LR lebih besar daripada nilai kritis LR maka dapat disimpulkan bahwa adanya kointegrasi sejumlah variabel, dan kebalikannya apabila nilai hitung LR lebih kecil jika dibandingkan dengan nilai kritisnya maka tidak menunjukkan danya kointegrasi. Berdasarkan hasil uji kointegrasi dengan pendekatan Johansen Cointegration, terlihat dalam jangka panjang masing-masing variabel terkointegrasi pada tingkat kepercayaan $5 \%$

Berdasarkan hasil perhitungan menunjukkan bahwa nilai trace statistik lebih besar dibandingkan dengan nilai kritis pada tingkat kepercayaan 5\% untuk $3 \mathrm{CE}$ (s) (None, at most 1, at most 2 dan at most 3), berarti saling berkointegrasi. Dari hasil uji konintegrasi diperoleh persamaan jangka panjang

\section{Error Corection Modelling Angel Granger}

Pendekatan error correction modeling (ECM) merupakan salah satu model time series yang digunakan untuk melihat keterpaduan antara jangka pendek dan jangka panjang dari variabelvariabel yang terdapat dalam model. Hubungan jangka panjang diterapkan dengan menggunakan vector coointegration kedalam model, sedangkan dinamika jangka pendek ditetapkan dengan mengikutsertakan variabel ECT. Variabel ECT adalah error dari persamaan regresi OLS Jangka Panjang. Dalam persamaan jangka pendek, maka nilai ECT dimasukkan dalam lag 1 atau ECT(-1). Syarat yang harus dipenuhi pada model persamaan jangka pendek koefisien ECT $(-1)$ bernilai negatif dan terletak antara 0 dan 1 serta signifikan secara statistik.

Hasil regresi pertama dari serangkaian regresi yang terkait dengan pengujian ECM, terlihat nilai ECT (-1) negatif dan signifikan secara statistik. Nilai negatif dari koefisien ECT (-1) ini mengindikasikan adanya fenomena pergerakan data jangka pendek yang bersifat mendekati keseimbangan jangka panjang, sehingga proses pengujian ECM bisa dilanjutkan. Jika nilai koefisien dari ECT pada regresi pertama dengan panjang lag tertentu tersebut positif, maka proses pengujian data dengan menggunakan metode ECM tidak dapat dilanjutkan karena pergerakan data bersifat menjauhi keseimbangan jangka panjang. Pada tabel di atas perhatikan nilai signifikansi residualnya nilai statistik t cukup tinggi (di atas 2) dan nilai probabilitasnya kurang dari 0,05, hal ini menunjukkan bahwa model korelasi kesalahan (ECM) yang digunakan sudah valid. Berdasarkan hasil pengujian yang sudah dilakukan sebelumnya atas data maka disajikan persamaan regresi sebagai berikut :

\footnotetext{
$\mathrm{NPF}=0,001-0,283 * \mathrm{D}($ Inflasi $)+$ $0,015 * D(K e b i j a k a n p e m b i a y a a n)$ $+2,244.10^{-07} * \mathrm{D}(\mathrm{GDP})-0,959641 *$ ECT(-1)
} 
Berdasarkan hasil perhitungan diketahui bahwa arah dari setiap kioefisian variabel sudah sesuai dengan arah yang ditetapkan pada saat penetapan hipotesis. Dengan demikian dapat disampaikan bahwa terdapat indikasi moral hazard pada perbankan syariah di Indonesia. Hal ini sesuai dengan penelitian sebelumnya yaitu Mustafa Edwin Nasution dan Ranti Wiliasih (2007) yang menyatakan bahwa untuk kasus BMI, rasio alokasi pembiayaan murabahah dibanding pembiayaan profit loss sharing (mudharabah dan musyarakah) menyebabkan adanya peningkatan kredit macet. Hal ini menggambarkan adanya indikasi moral hazard di BMI, karena ketidakhati-hatian BMI yang mengakibatkan terjadinya indikasi moral hazard pada sisi debitur. Jumlah komposisi yang seimbang antara pembiayaan dengan skema murabahah dan mudharabah, menyebabkan BMI melaksanakan pengawasan yang lebih ketat untuk debitur pembiayaan musyarakah dan mudharabah, akan tetapi namun kurang waspada terhadap pembiayaan murabahah. Adanya indikasi moral hazard menujukkan bahwa sistem di bank syariah masih harus dibenahi terutama pada saat melakukan penilaian kelayakan calon debitur, sistem pengawasan dan sistem operasional lainnya yang bisa menyebabkan tereduksinya moral hazard di sisi nasabah.

Model ekonometri yang digunakan untuk melihat ada tidaknya indikasi moral hazard di bank syariah adalah dengan melihat faktor-faktor yang bisa mempengaruhi besaran rasio $N P F$ di bank syariah. Model ini diestimasi dengan menggunakan pendekatan error correction model. Dari hasil analisa data, ditemukan hubungan jangka pendek, sedangkan analisis hubungan jangka panjang ditemukan dari hasil regresi OLS kointegrasi.

Berikut hasil analisis data dengan menggunakan pendekatan ECM dan konitegrasi jangka panjang.

Persamaan jangka pendek

$\mathrm{NPF}=0,001-0,283 * \mathrm{D}($ Inflasi $)+$ $0,015 * D(K e b i j a k a n p e m b i a y a a n)$ $+2,244.10$
ECT $(-1)$

Berdasarkan hasil uji model ekonometri dengan pendekatan ECM, maka pada persamaan jangka pendek terlihat arah koefisien variabel ECT (-1) yang negatif, dengan besaran $-0,959641$. Variabel ini menunjukkan hasil yang signifikan secara statistik pada level kepercayaan $5 \%$. Sehingga hal ini menunjukkan adanya fenomena keseimbangan pada jangka pendek dan mendukung keseimbangan pada jangka panjang. Dari model jangka pendek ini terlihat bahwa variabel-variabel signifikana pada tingkatan kepercayaan 5\% dengan arah yang sesuai dengan hipotesis.

Hasil dari persamaan tersebut menunjukkan arah koefisien dari variabel yang sesuai dengan hipotesis. GDP dan kebijakan pembiayaan memiliki arah yang positif sedangkan inflasi memiliki arah yang negatif. Untuk variabel GDP, setiap peningkatan $1 \%$ GDP akan meningkatkan 2,24\% NPF di bank syariah. Kondisi yang mengisyaratkan adanya indikasi moral hazard ini signifikan pada tingkat kepercayaan $5 \%$.

Hal yang sama terjadi pada variabel kebijakan pembiayaan yaitu variabel yang merepresentasikan rasio alokasi pembiayaan murabahah terhadap pembiayaan bagi hasil. Besaran koefisien variabel sebesar 0,015 mempunyai arti bahwa setiap 
peningkatan $1 \%$ dari rasio pembiayaan murabahah terhadap pembiayaan bagi hasil akan meningkatkan peningkatan non performing financing sebesar $0,0,15 \%$ dimana hal ini signifikan pada tingkat kepercayaan $5 \%$.

Sementara itu untuk variabel inflasi mempunyai koefisien negatif sebesar 0,283 yang mempunyai arti setiap penurunan inflasi sebesar $1 \%$ akan meningkatkan non performing financing sebesar 0,283\%, hal ini signifikan pada tingkat kepercayaan $5 \%$. Berdasarkan ketiga variabel yang digunakan dalam melihat adanya indikasi moral hazard di bank syariah terlihat signifikan pada tingkat kepercayaan $5 \%$ dengan arah yang sesuai dengan yang ditetapkan pada hipotesis. Dengan demikian berdasarkan persamaan jangka panjang terlihat adanya indikasi moral hazard di bank syariah

\subsection{Pembahasan.}

GDP dan inflasi dalam model ini merepresentasikan kondisi makroekonomi tepatnya sektor riil. Pada saat sektor riil mengalami pertumbuhan positif, idealnya terjadi peningkatan transaksi dan aktivitas perekonomian. Sehingga kondisi bisnis pada umumnya berada pada kondisi yang lebih baik. Keadaan yang lebih baik tersebut seharusnya akan memberikan dampak positif terhadap hasil yang diperoleh. Hal yang sebaliknya terjadi bila pertumbuhan perekonomian mengalami pertumbuhan negatif sebagaimana diungkapkan oleh Kittikulsing (2002) yang menyatakan bahwa dalam kondisi pertumbuhan GDP Riil -10 \%. Hampir setengah dari pinjaman yang diberikan akan macet. Hal yang sama diungkapkan oleh wu chang yang menyatakan bahwa pada saat kondisi perekonomian yang dilihat dari indikator makroekonomi dalam kondisi baik, maka idealnya NPF akan rendah.

Selaian itu pengaruh kebijakan alokasi pembiayaan, terhadap indikasi moral hazard, dapat dilihat dari kontribusi alokasi pembiayaan terhadap pembentukana nilai NPF yang ditujukan oleh koefisien dari Kebijakan Pembiayaan dalam persamaan jangka pendek maupun jangka panjang. Dalam jangka pendek terlihat bahwa pembiayaan 6 bulan yang lalu meberikan gambaran adanya indikasi moral hazard. Ini dikarenkan besaran koefisien bernilai positif dan signifikan secara statistik. Hal ini didukung oleh variabel ECT yanag signifikan pada tingkat kepercayaan $5 \%$ sehingga fenomena jangka pendek sahih secara stataistik. Sedangkan untuk persamaan jangka panjang, besaran koefisien variabel memiliki arah yang searah dengan KP di persaamaan jangka pendek, yaitu positif sebesar 0,015. Besaran koefisien sebesar 0,015 berarti menunjukkakan setiap peningkatan $1 \%$ ratio pembiayaan murabahah dengan pembiayaan bagi hasil akan meningkatkana non performing financing sebesar 0,015 . Hal ini menggambarkan kondisi yang sudah sesuai dengan hipotesis yang diharapkan.

Pembiayaan murabahah yang low risk dapat mengakibatkan moral hazard tentunya tidak terlepas dari sistem bank yang memberikan kesempatan terjadinya moral hazard disisi debitur. Dalam hal ini ada dua hal yang dapat menjelaskan mengapa terjadi pembiayaan macet pada pembiayaan murabahah.

1. Kesalahan bank dalam melakukan assestment terhadap calon debitur. Bank syariah belum memiliki sistem khusus dalam menilai kelayakan calon nasabah. Keberadaan pusat 
informasi yang menyediakan list debitur yang tidak bertanggungjawab sangat dibutuhkan, sehingga tidak terjadi kasus yang ditolak di bank konvensional lari ke bank syariah.

2. Bank syariah masih kurang dalam upaya melakukan monitoring, terutama kepada nasabah murabahah. Kelalaian dalam melakukan monitoring bisa menyebabkan indikasi moral hazard di sisi nasabah, misalnya nasabah menjadi malas membayar angsuran.

\section{Kesimpulan}

Merujuk pada hasil penelitian, pengujian hipotesis dan analisis pembahasan yang telah dipaparkan sebelumnya maka dapat dikemukan

\section{DAFTAR PUSTAKA}

Belkaoui. (2001). Accounting Theory, Horcourt Brace and Company

Blum,Jurg.(2002). The Limits of Market discipline in reducing bank's risk taking. Journal of Banking an Finance

Cooper Donald R. Pamela S. Scindler (2006). Business Research Methods, $9^{\text {th }}$ edition,Mc Graw Hill. Irwin

Covietz,Daniel and Erick Hetfiel.(2004).Monitoring,Mor al Hazard and Market Power:A Model Of Bank Lending

Dar,A Humayon, David and Jhon Presley.(2001). Size, Probability, and Agency cost in Profit loss sharing In Islamic Banking and Finance.

Dendawijaya, Lukman. 2003. Manajemen Perbankan.

Jakarta: Penerbit Ghalia Indonesia. kesimpulan penelitian bahwa terdapat Indikasi Moral hazard penyaluran pembiayaan pada perbankan syariah di Indonesia. Kesimpulan ini diperoleh berdasarkan hasil pengujian menggunakan Error correction modelling yang menghasilkan persamaan jangka pendek dan terkointegrasi menuju keseimbangan jangka panjang. Analisa dilakukan dengan menggunakan indikator Non Performing Financing sebagai outcome dari kebijakan bank syariah dalam mengelola pembiayaan dan variabel variabel penentunya adalah variabel makroekonomi yang terdiri dari GDP dan Inflasi serta varioabel kebijakan internal yaitu kebijakan pembiayaan

Ding Lu, Shandre, Qing Hu.(2001).The Link Between Bank Behaviour and Non Performing Loan In China

Drajat Wibowo (2007). Biayai Properti, NPF Bank Syariah Naik. Republika. Internet.

Dreher, Axel. (2004). Does the IMF cause Moral Hazard? A Critical review of The Evidance, paper

Djohanputro, Bramantyo dan Ronny Kountur. (2007), Non Performing Loan (NPL) Bank Perkreditan Rakyat. Internet.

Erlend Nier and Ursel Bauman.(2003). Marklet Disipline, Disclosure and Moral Hazard. April

Gaynor, Martin dan Paul Gertler.(1995).Moral hazard and Risk Spreading in Partnership.Jurnal.Volume 26.No4

Gujarati, Dhamodar (2003). Basic Econometrics. Fourth edition. Mc Graw Hill.New York.USA 
Hari Prasetya (2005).LPS dan Upaya Meningkatkan Disiplin Pasar . Jakarta jurnala riset bisnis

Insukindro. (1993), Ekonomi Uang dan Bank. BPFE, UGM, Yogyakarta.

Irfan, Ali. (2002),Pelaporan Keuangan dan Asimetri Informasi dalam Hubungan Agensi. Lintasan Ekonomi, Vol. XIX No. 2, Juli 2002.

James HM Sprayregen, etc, Non Performing Loan In china a potensial win-win opportunity for foreign investors and china economy.

Jensen \& Meckling. (1976), Theory of The Firm : Managerial Behaviour, Agency Cost and ownership structure, Journal of Finance Economic Desember.

Khomsiyah, (2003). Hubungan Corporate Governance dan Pengungkapan Informasi: Pengujian secara Simultan. Proceeding Simposium Nasional Akuntansi VI, Surabaya, 16-17 Oktober 2003, hal. 200-209.

Khomsiyah dan Susanti (2003). Pengungkapan, Asimetri Informasi dan Cost of Capital. Proceeding Simposium Nasional Akuntansi VII, Surabaya, 16-17 Oktober 2003, hal. 1008-1018.

Haron Sudin ((1994),Islamic Banking in Malaysia.

Masri Singarimbun dan Sofyan Effendi (1995), Metode Penelitian Survey, cetakan kedua, Jakarta

Mettawa \& Almossawi .(1998).Banking Behaviour of Islamic Bank Customer: perspectives and implications. The International journal Of Bank Marketing Volume 16 number 71998

Mayes, David G, Liisa Halme and Aarno Liuksila(2001), Improving Banking Supervision,Palgrave,Mcmillan

Mishkin, Frederick (2001) 'Financial Policies and the Prevention of Financial Crises in Emerging Market Countries', NBER Working Paper No. 8087, January.

Mohamad

Fany Alfarist(2004),Korupsi dan Perkembangan Perbankan syariah. internet

Muhammad

(2005),Manajemen Pembiayaan Bank Syar

Muhammad

Syafi' I Antonio.(2001).Bank Syariah dari Teori Ke Praktek.Jakarta;Gema Insani Pers, 2001

Mustafa Edwin Nasution dan Ranti Wiliasih, (2007), Profit Sharing dan Moral Hazard dalam Penyaluran Dana Pihak Ketiga Bank Umum Syariah Jurnal Ekonomi dan Pembangunan Indonesia Vol. VII No. 02, hal 105-129.

Naser, Kamal; Jamal Ahmad AlKhatib.(1999). A Study Of customer satisfaction and Preferrence in Jordan Islamic Banking. International Journal Of Bank Marketing 17,3 MCB University Press.

Rizal Yahya, Ahim Abdurrahim, Peni Nugraheni.(2008).

Kesenjangan Harapan Antara Nasabah dan Manajemen Terhadap Penyampaian 
Informasi Keuangan dan Non Keuangan Bank Syariah. Studi Empiris Bank Syariah di Yogyakarta dan Surakarta, Proceeding Simposium Nasional Akuntansi ke XI, Oktober 2008, hal.

Sayantan Ghossal \& Marcus Miller .(2003).Coordination failure, moral hazard and sovereign bankrupty procedures. Economic \& Social Research
Council (ESRC) Centre for the Studdy of Globalization and Regionalisation, University of Warwick United Kingdom

Scott, William (1997).Financial Accounting Theory. Upper Sadle River,New Jersey:Prentice Hall

Sofyan Rizal, Kontrak Mudharabah Permasalahan dan Alternatif Solusi. Jurnal Ekonomi Islam Volume 3 